Supporting Information

\title{
Practical Aqueous Calcium-ion Battery Full-cells for Future Stationary Storage
}

Md. Adir', Ananta Sarkar', Amlan Roy'1, Manas Ranjan Panda,1,2, Abharana Nagendra²

and Sagar Mitra ${ }^{1 *}$

${ }^{1}$ Electrochemical Energy Laboratory, Department of Energy Science and Engineering, Indian

Institute of Technology Bombay, Powai, Mumbai - 400076, India

${ }^{2}$ IITB-Monash Research Academy, Mumbai - 400076, India

${ }^{3}$ Bhabha Atomic Research Centre, Mumbai 400085, India

\section{Corresponding Author}

Electrochemical Energy Laboratory,

Department of Energy Science and Engineering,

Indian Institute of Technology Bombay, Powai, Mumbai-400076, India. 


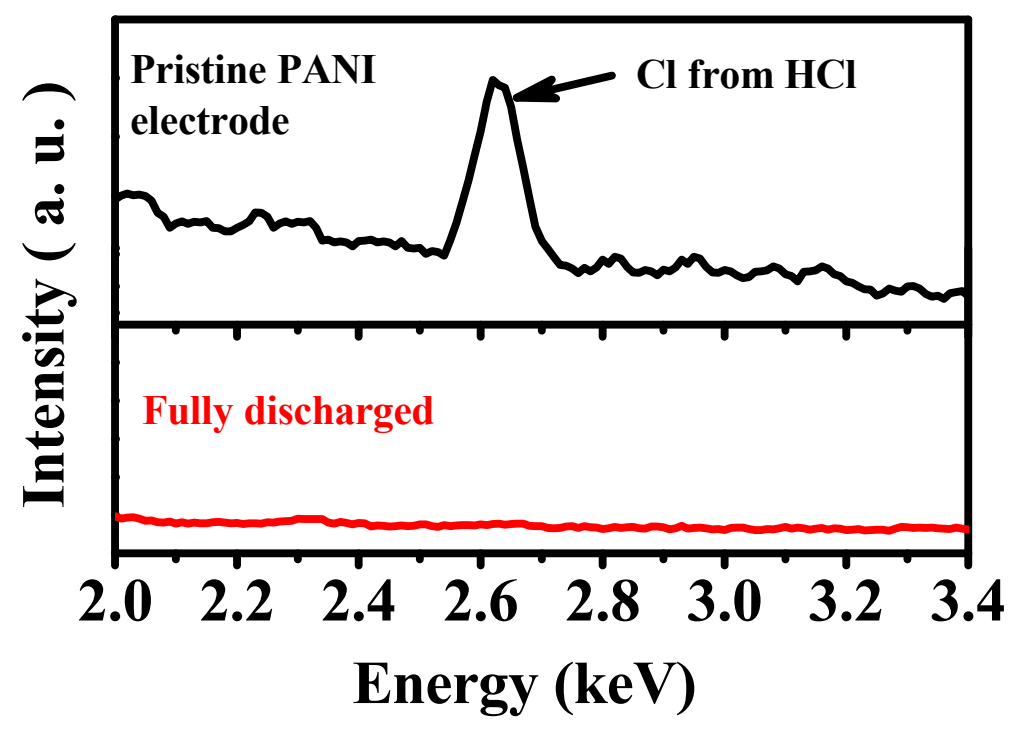

Figure S1. EDS of $\mathrm{Cl}$ in the pristine and discharged PANI/CC electrode, suggesting the absence of the $\mathrm{Cl}^{-}$dopant after the discharge process.

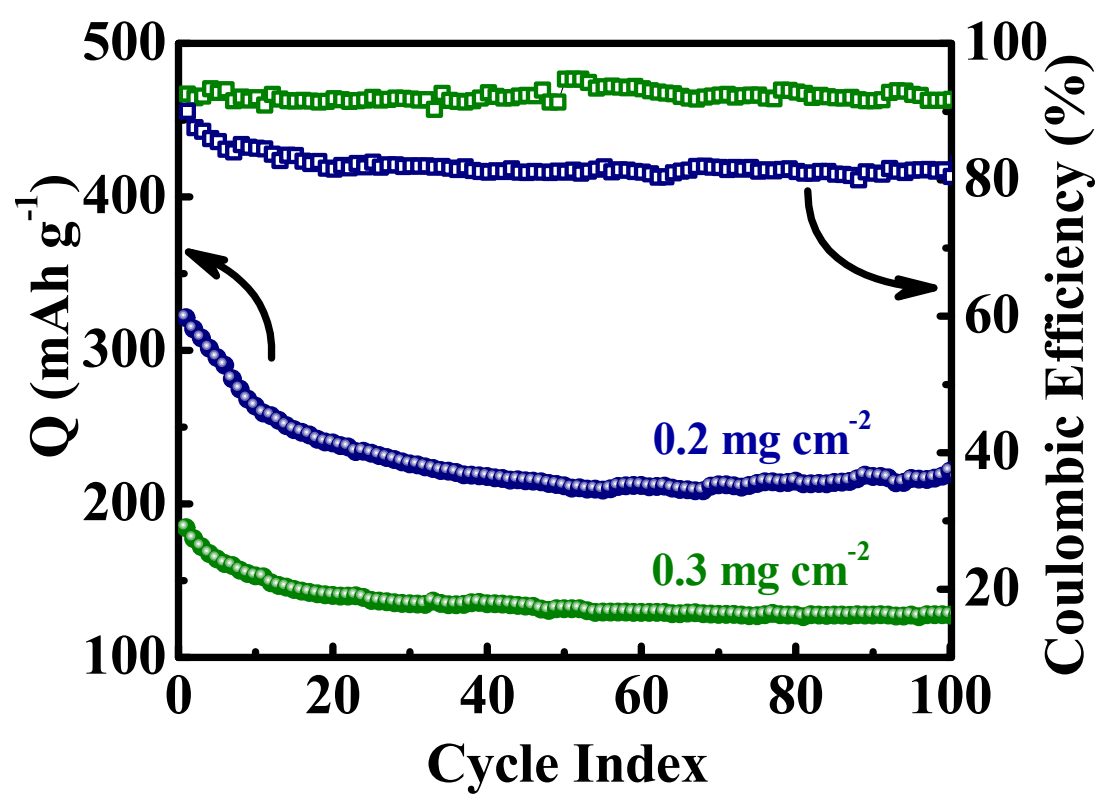

Figure S2. Cycling performance of anode with different loading (blue: $0.2 \mathrm{mg} / \mathrm{cm}^{2}$; olive green: $0.3 \mathrm{mg} / \mathrm{cm}^{2}$ ) of anode at the current rate of $0.15 \mathrm{~A} \mathrm{~g} \mathrm{~g}^{-1}$. 


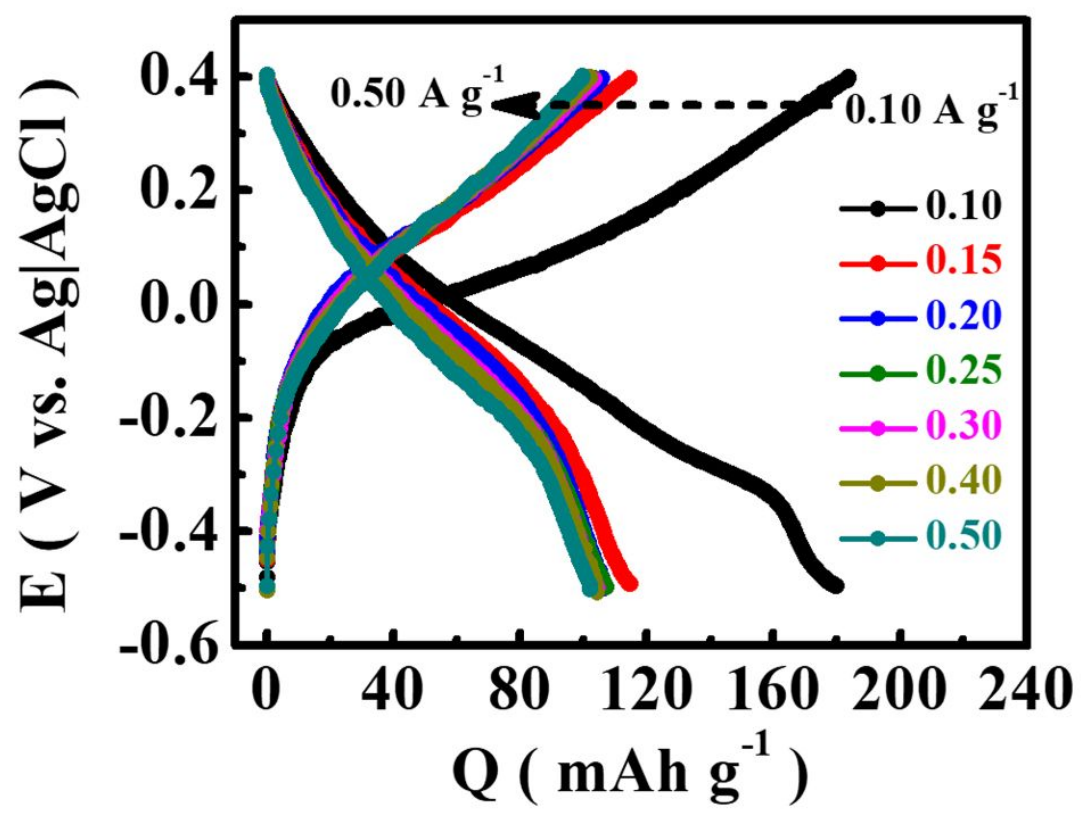

Figure S3. Galvanostatic charge-discharge profile of the PANI/CC anode at different current rates at $20^{\circ} \mathrm{C} \pm 2^{\circ} \mathrm{C}$ accuracy.

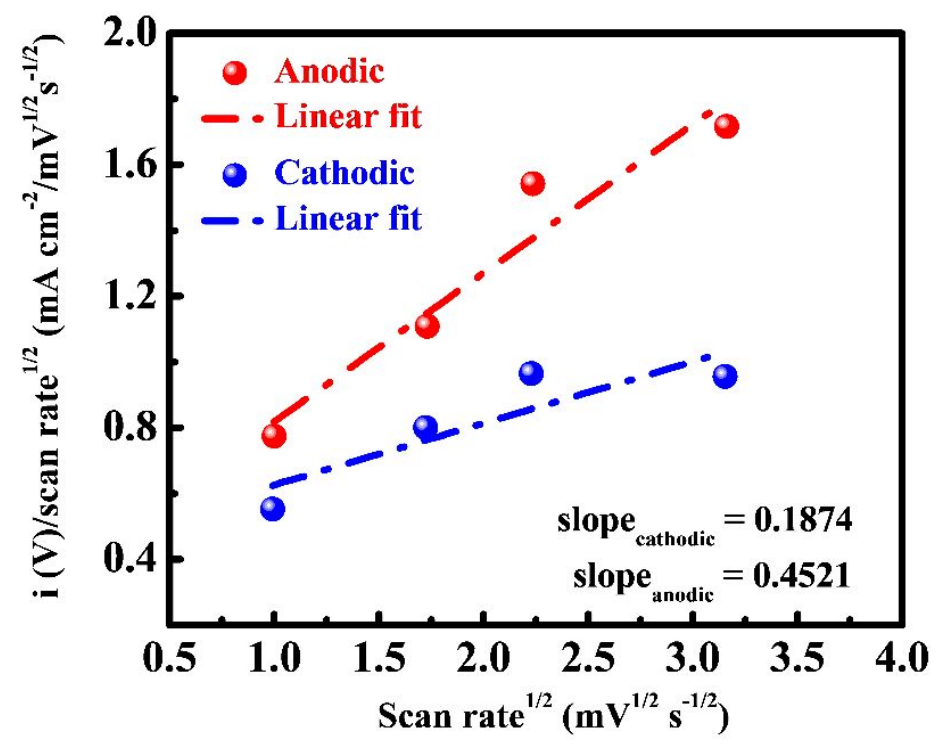

Figure S4. The plot of the current/square root of the scan rate $\left(\mathrm{i}(\mathrm{V}) / \mathrm{scan}\right.$ rate $\left.^{1 / 2}\right)$ versus the square root of the scan rates for the PANI/CC anode. 
(a)

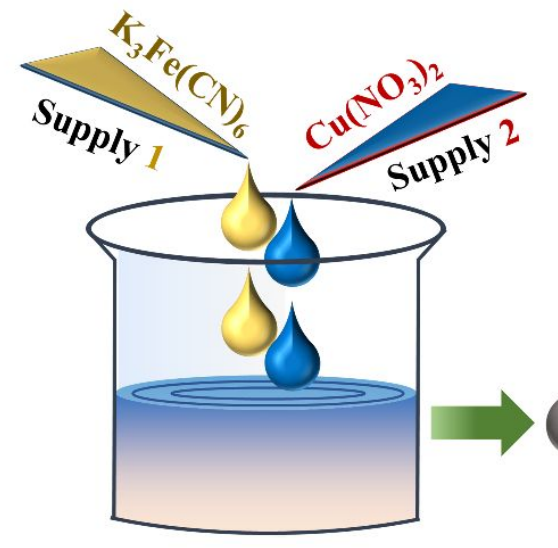

(b)

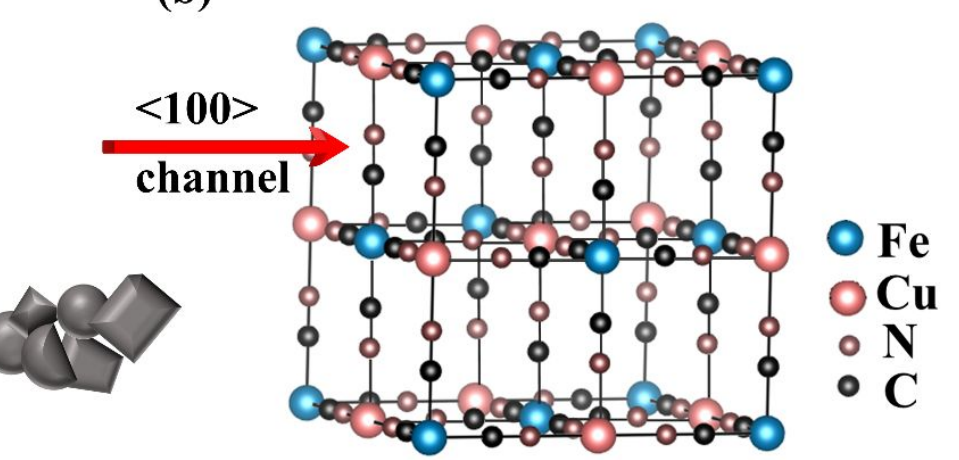

Figure S5. (a) Schematic diagram of the preparation of nanoparticles of potassium copper hexacyanoferrate, (b) The corresponding lattice structure of potassium copper hexacyanoferrate, showing an open channel along the $<100>$ direction. (software used: Vesta ${ }^{1}$ )

Table S1. Atomic position value for as-prepared potassium copper hexacyanoferrate powder FullProf Fitting Parameters:

Bragg R-factor $=6.32$

RF-factor $=7.56$

$\chi^{2}=0.915$

Atomic positions

\begin{tabular}{|l|c|c|c|c|c|c|}
\hline & Label & $\mathbf{X}$ & $\mathbf{Y}$ & $\mathbf{Z}$ & $\mathbf{B}$ & Occupancy \\
\hline Atom \# 1 & $\mathrm{K} 1$ & 0.02496 & 0.02496 & 0.02496 & -2.10929 & 0.61334 \\
\hline Atom \# 2 & $\mathrm{K} 2$ & 0.25000 & 0.25000 & 0.25000 & 2.44975 & 0.23090 \\
\hline Atom \# 3 & $\mathrm{Cu} 1$ & 0.50000 & 0.50000 & 0.50000 & -0.32742 & 0.54181 \\
\hline Atom \# 4 & $\mathrm{Fe} 1$ & 0.00000 & 0.00000 & 0.00000 & 6.63734 & 0.36853 \\
\hline Atom \# 5 & $\mathrm{C} 1$ & 1.58855 & 0.00000 & 0.00000 & 10.16919 & -1.25642 \\
\hline Atom \# 6 & $\mathrm{N} 1$ & 1.29359 & 0.00000 & 0.00000 & 0.19564 & 4.07735 \\
\hline Atom \# 7 & $\mathrm{O} 1$ & 8.79927 & 0.00000 & 0.00000 & -0.40837 & 1.12836 \\
\hline Atom \# 8 & $\mathrm{O} 2$ & 0.25000 & 0.25000 & 0.25000 & 8.79953 & -0.18649 \\
\hline Atom \# 9 & $\mathrm{O} 3$ & 0.28554 & 0.28554 & 0.28554 & 13.38554 & 1.08396 \\
\hline
\end{tabular}


FWHM Parameters

\begin{tabular}{|l|l|l|l|}
\hline & U & V & W \\
\hline Coefficients & 0.618120 & -0.333767 & 0.073114 \\
\hline
\end{tabular}

\section{Calculation of empirical formula of potassium copper hexacyanoferrate}

\section{Data recorded from ICP-AES}

Total weight of the sample $=0.10571$ gram

Weight $\%$ of $\mathrm{Cu}=22.265$, Weight $\%$ of $\mathrm{Fe}=12.602$ and weight $\%$ of $\mathrm{K}=0.306$

Since we know that

$$
\text { Weight } \% \text { of element }=\frac{\text { weight o f element }}{\text { Total weight of sample }} \times 100
$$

For Copper $\quad \frac{22.265}{100}=\frac{\text { weight of } \mathrm{Cu}}{0.10571}$

Therefore, weight of $\mathrm{Cu}=0.0235$ gram

Similarly, weight of $\mathrm{Fe}=0.01332$ gram and weight of $\mathrm{K}=0.000323$ gram

Since we know that the number of moles $=\frac{\text { Weight of the element }}{\text { molecular weight of the element }}$

Therefore, Mole of $\mathrm{Cu}=\frac{0.0235}{63.546}=0.000369$

$$
\text { Mole of } \mathrm{Fe}=\frac{0.01332}{55.846}=0.000238
$$




$$
\text { Mole of } K=\frac{0.000323}{39.098}=0.00000826
$$

Now, dividing the each mole with 0.000369 (since we have calculated with respect to $\mathrm{Cu}$ )

Therefore, $\mathrm{Cu}=\frac{0.000369}{0.000369}=1$

$$
\begin{aligned}
& \mathrm{Fe}=\frac{0.000238}{0.000369}=0.64 \\
& \mathrm{~K}=\frac{0.00000826}{0.000369}=0.02
\end{aligned}
$$

So the empirical formula is $\mathrm{K}_{0.02} \mathrm{Cu}\left[\mathrm{Fe}(\mathrm{CN})_{6}\right]_{0.64}$

\section{$\underline{\text { Calculation of Zeolitic water }}$}

Molecular formula weight of $\mathrm{K}_{0.02} \mathrm{Cu}\left[\mathrm{Fe}(\mathrm{CN})_{6}\right]_{0.64}$

$=(39.098 * 0.02)+(63.546)+(55.846 * 0.64)+(12.0107+14.0067) * 6$

$=256.173$ gram mole -1 $^{-1}$

Loss of water calculated from TGA curve $=39 \% \quad$ (Figure S6a)

Therefore weight ratio (\%)

$\mathrm{K}_{0.02} \mathrm{Cu}\left[\mathrm{Fe}(\mathrm{CN})_{6}\right]_{0.64}:$ water

\begin{tabular}{|c|c|}
\hline 61 & 39 \\
\hline$\overline{256.173}$ & $\overline{18}$ \\
\hline 0.238 & 2.166 \\
\hline
\end{tabular}

$61 \% \quad: \quad 39 \%$

Mole ratio 


$\begin{array}{ccc}\frac{0.238}{0.238} & : & \frac{2.166}{0.238} \\ 1 & : & 9.1\end{array}$

So, the final formula is represented as $\mathrm{K}_{0.02} \mathrm{Cu}\left[\mathrm{Fe}(\mathrm{CN})_{6}\right]_{0.64} \cdot 9 \mathrm{H}_{2} \mathrm{O}$

(a)

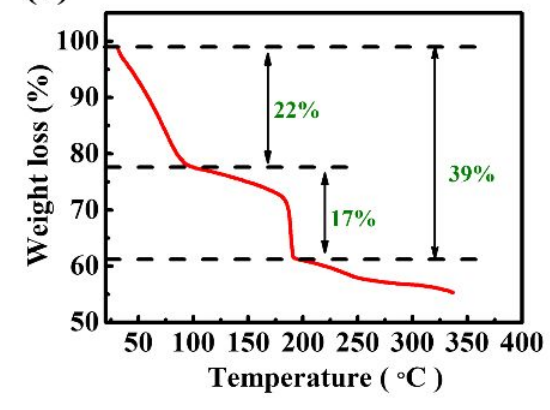

(b)

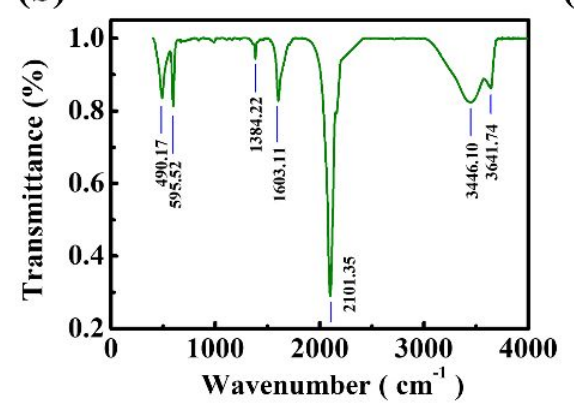

(c)

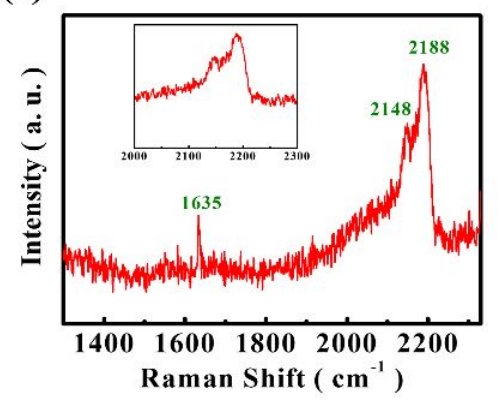

Figure S6. (a) Thermogravimetric analysis, (b) Fourier transform infrared spectroscopy, and (c) Laser Raman spectroscopy of potassium copper hexacyanoferrate nanoparticles. 
(a)

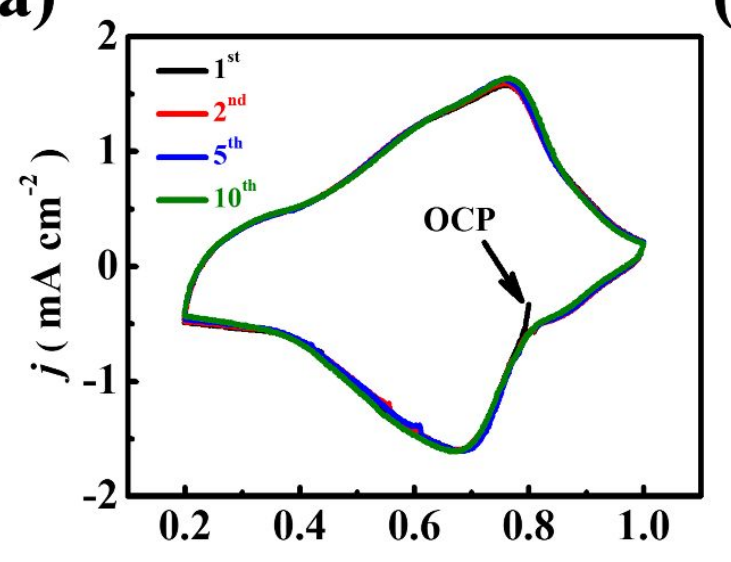

(c)

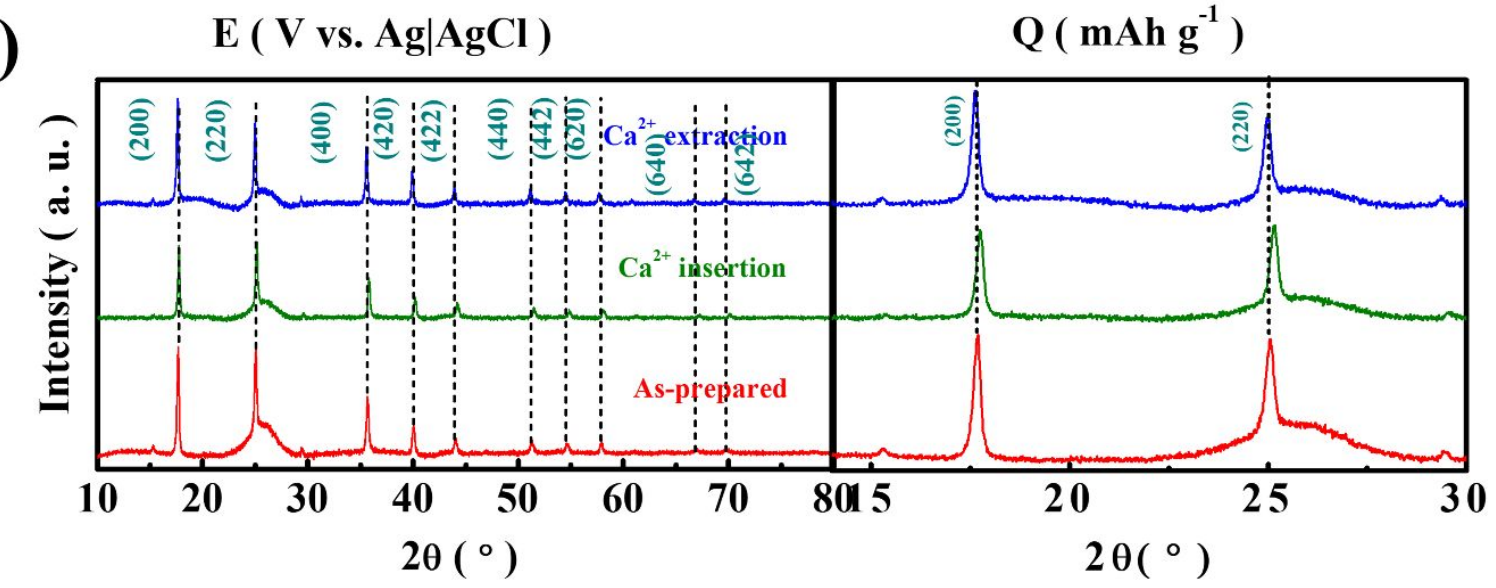

(b)

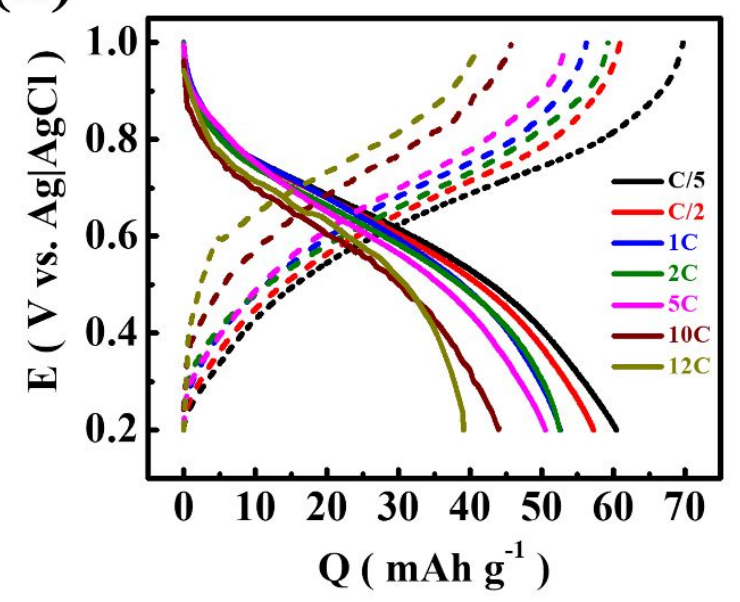


Table S2. Best fit data of EXAFS fitting for all samples at the Fe K-edge.

\begin{tabular}{|c|c|c|c|c|}
\hline & & As-prepared & Fully oxidized & Fully reduced \\
\hline Fe-C & $\mathrm{CN}(6)$ & $5.4 \pm 0.3$ & $5.9 \pm 0.3$ & $4.2 \pm 0.2$ \\
\hline & $R(1.87)$ & $1.92 \pm 0.03$ & $1.92 \pm 0.02$ & $1.88 \pm 0.01$ \\
\hline & $\sigma^{2}$ & $0.003 \pm 0.001$ & $0.003 \pm 0.001$ & $0.003 \pm 0.001$ \\
\hline $\mathrm{Fe}-\mathrm{C}+\mathrm{N}$ & $\mathrm{CN}(12)$ & $11.1 \pm 0.5$ & $11.7 \pm 0.4$ & $9.97 \pm 0.3$ \\
\hline & $R(3.01)$ & $3.07 \pm 0.02$ & $3.08 \pm 0.03$ & $3.01 \pm 0.02$ \\
\hline & $\sigma^{2}$ & $0.003 \pm 0.001$ & $0.003 \pm 0.001$ & $0.003 \pm 0.001$ \\
\hline
\end{tabular}

Table S3. Best fit data of EXAFS fitting for all samples at the $\mathrm{Cu}$ K-edge.

\begin{tabular}{|c|c|c|c|c|}
\hline & & As-prepared & Fully oxidized & Fully reduced \\
\hline $\mathrm{Cu}-\mathrm{N}$ & $\mathrm{CN}(6)$ & $5.1 \pm 0.1$ & $5.4 \pm 0.1$ & $4.6 \pm 0.1$ \\
\hline & $R(2.04)$ & $1.85 \pm 0.03$ & $1.90 \pm 0.02$ & $1.89 \pm 0.01$ \\
\hline & $\sigma^{2}$ & $0.003 \pm 0.001$ & $0.003 \pm 0.001$ & $0.003 \pm 0.001$ \\
\hline $\mathrm{Cu}-\mathrm{C}$ & $\mathrm{CN}(6)$ & $5.1 \pm 0.1$ & $5.4 \pm 0.1$ & $4.6 \pm 0.1$ \\
\hline & $R(3.17)$ & $3.14 \pm 0.02$ & $3.16 \pm 0.03$ & $3.13 \pm 0.02$ \\
\hline & $\sigma^{2}$ & $0.008 \pm 0.003$ & $0.006 \pm 0.002$ & $0.006 \pm 0.002$ \\
\hline $\mathrm{Cu}-\mathrm{C}+\mathrm{N}$ & $\mathrm{CN}(12)$ & $10.3 \pm 0.2$ & $10.8 \pm 0.2$ & $9.1 \pm 0.3$ \\
\hline & $R(3.17)$ & $3.14 \pm 0.02$ & $3.16 \pm 0.03$ & $3.13 \pm 0.02$ \\
\hline & $\sigma^{2}$ & $0.009 \pm 0.004$ & $0.007 \pm 0.002$ & $0.006 \pm 0.002$ \\
\hline
\end{tabular}



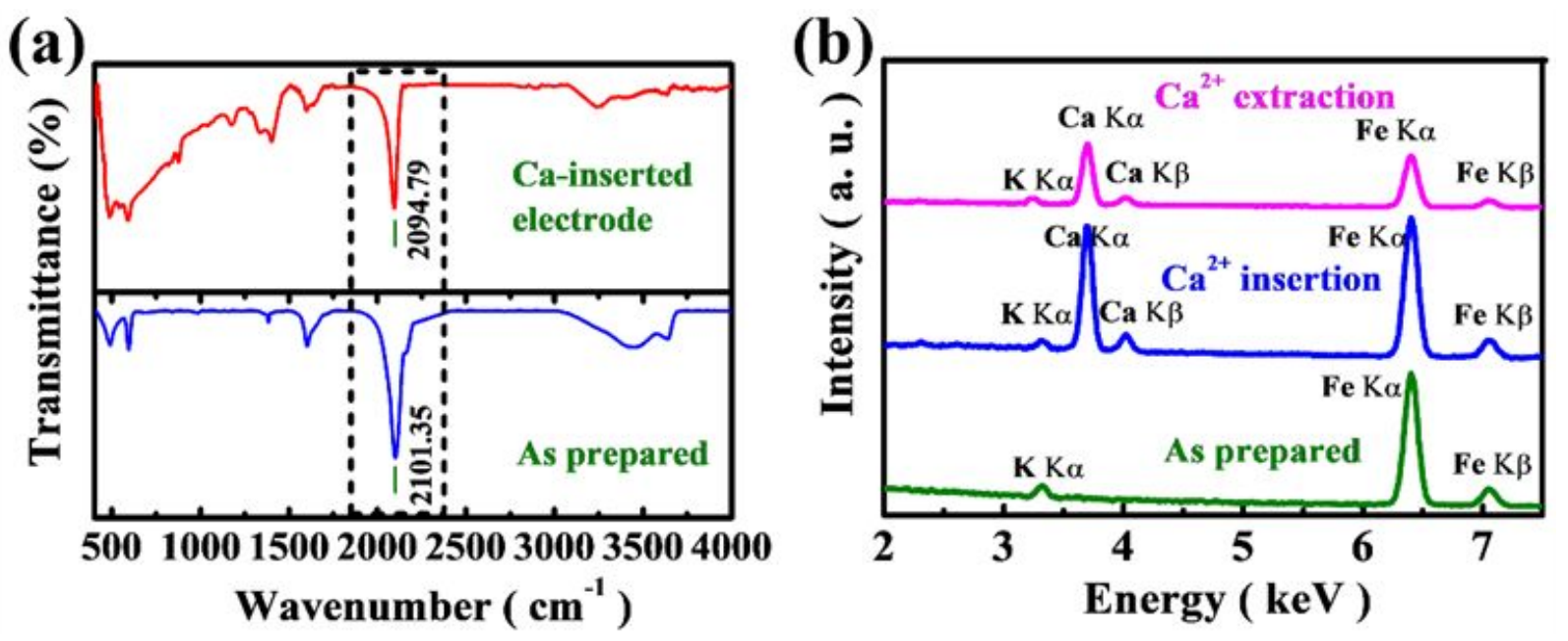

Figure S8. FTIR spectra of (a) as-prepared and Ca-inserted electrodes. (b) EDS of as-prepared, Ca-inserted, and $\mathrm{Ca}$-extracted $\mathrm{CuHCF}$ electrodes.

(a)
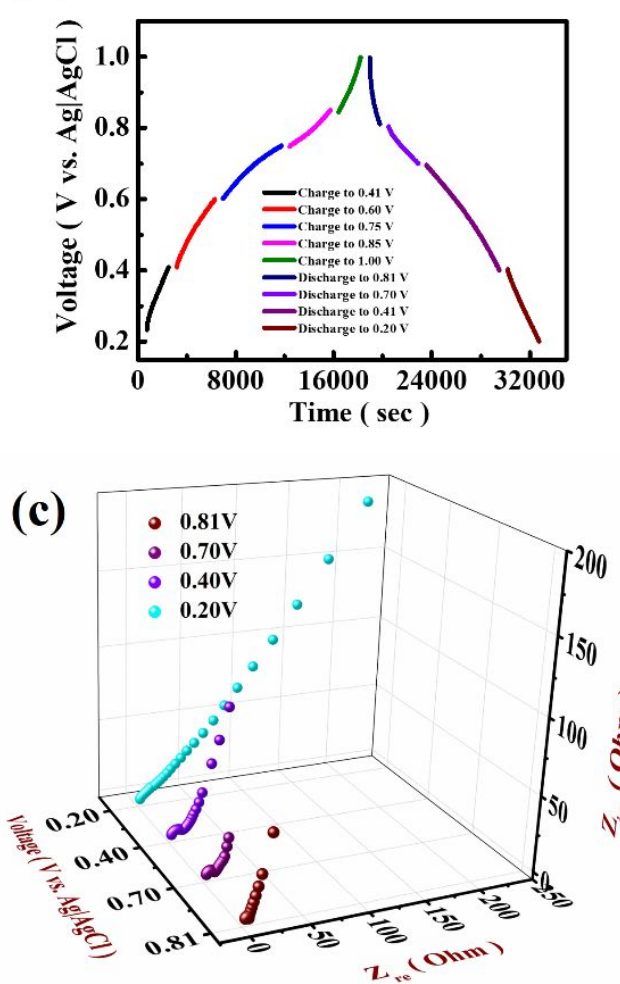

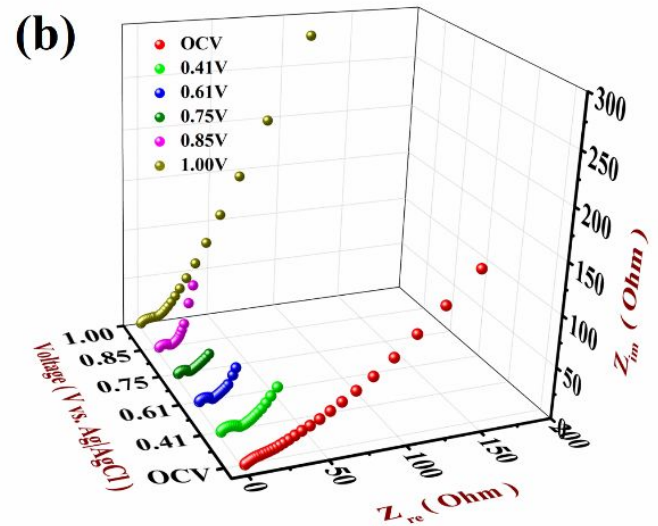

(d)

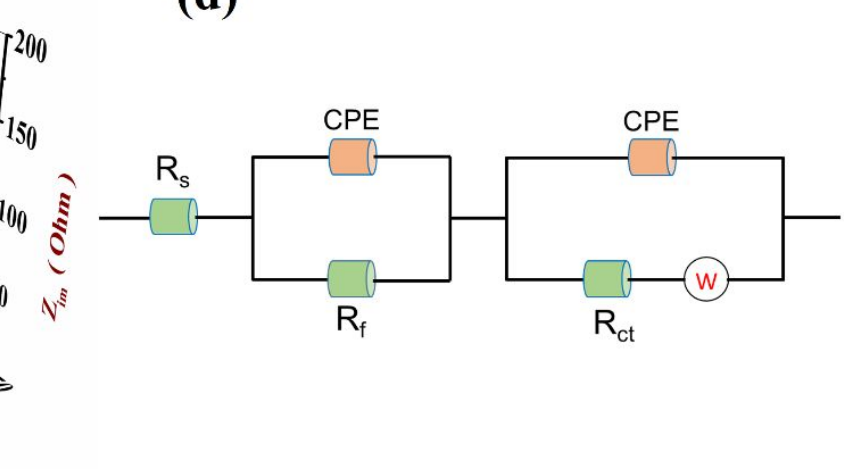

Figure S9. (a) The charge-discharge curves of $\mathrm{Ca}_{\mathrm{x}} \mathrm{CuHCF}$ to different potentials at a current rate of $20 \mathrm{~mA} \mathrm{~g}^{-1}$ in a $2.5 \mathrm{M} \mathrm{Ca}\left(\mathrm{NO}_{3}\right)_{2}$ aqueous electrolyte. EIS spectra of $\mathrm{Ca}_{\mathrm{x}} \mathrm{CuHCF}$ (b) $1^{\text {st }}$ charged process, (c) $1^{\text {st }}$ discharged process and (d) the equivalent circuit used to fit the EIS spectra. 
(a)

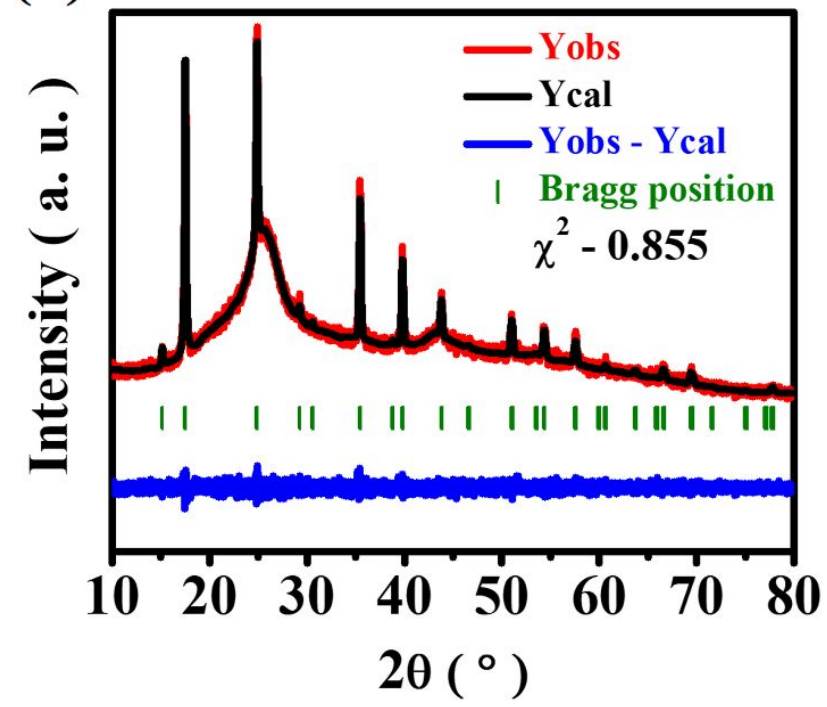

(b)

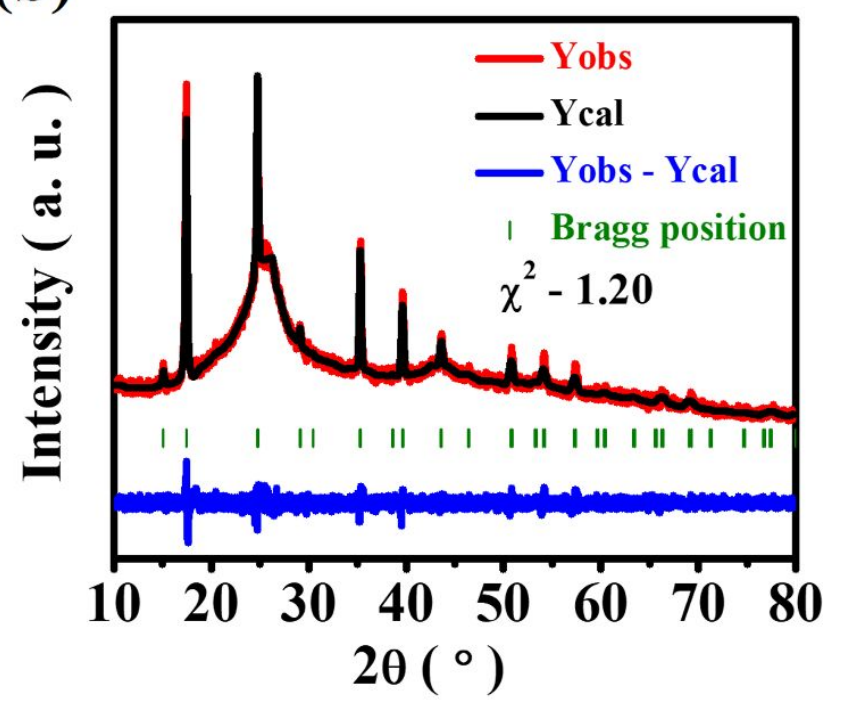

Figure S10. X-ray diffraction pattern (red line) with Rietveld refinement fits (black line) of the (a) discharged electrode and (b) charged electrode.

Table S4. Atomic position value for the discharged electrode FullProf Fitting Parameters:

$\chi^{2}=0.855$

\section{Atomic positions (Discharged electrode)}

\begin{tabular}{|l|c|c|c|c|c|c|}
\hline & Label & $\mathbf{X}$ & $\mathbf{Y}$ & $\mathbf{Z}$ & $\mathbf{B}$ & Occupancy \\
\hline Atom \# 1 & $\mathrm{K} 1$ & 0.02109 & 0.02109 & 0.02109 & -4.24022 & 0.55698 \\
\hline Atom \# 2 & $\mathrm{K} 2$ & 0.25000 & 0.25000 & 0.25000 & 2.24177 & 0.23319 \\
\hline Atom \# 3 & $\mathrm{Cu} 1$ & 0.50000 & 0.50000 & 0.50000 & -8.26988 & 0.39996 \\
\hline Atom \# 4 & $\mathrm{Fe} 1$ & 0.00000 & 0.00000 & 0.00000 & -6.82969 & 0.18349 \\
\hline Atom \# 5 & $\mathrm{C} 1$ & 1.58043 & 0.00000 & 0.00000 & 15.81357 & -1.40497 \\
\hline Atom \# 6 & $\mathrm{N} 1$ & 1.29516 & 0.00000 & 0.00000 & 1.62216 & 4.28353 \\
\hline Atom \# 7 & $\mathrm{O} 1$ & 8.80653 & 0.00000 & 0.00000 & -3.21218 & 1.03594 \\
\hline Atom \# 8 & $\mathrm{O} 2$ & 0.25000 & 0.25000 & 0.25000 & 8.59102 & 0.23567 \\
\hline Atom \# 9 & $\mathrm{O} 3$ & 0.28460 & 0.28460 & 0.28460 & 22.65288 & 0.67964 \\
\hline
\end{tabular}

FWHM Parameters

\begin{tabular}{|l|l|l|l|}
\hline & U & V & W \\
\hline Coefficients & 0.394632 & -0.073447 & 0.053327 \\
\hline
\end{tabular}


Table S5. Atomic position value for the charged electrode

FullProf Fitting Parameters:

$\chi^{2}=1.20$

Atomic positions (Charged electrode)

\begin{tabular}{|l|c|c|c||c|c|c|}
\hline & Label & $\mathbf{X}$ & $\mathbf{Y}$ & $\mathbf{Z}$ & $\mathbf{B}$ & Occupancy \\
\hline Atom \# 1 & $\mathrm{K} 1$ & 0.01893 & 0.01893 & 0.01893 & -3.57976 & 0.82268 \\
\hline Atom \# 2 & $\mathrm{K} 2$ & 0.25000 & 0.25000 & 0.25000 & 3.17572 & 0.24000 \\
\hline Atom \# 3 & $\mathrm{Cu} 1$ & 0.50000 & 0.50000 & 0.50000 & -3.00056 & 0.53756 \\
\hline Atom \# 4 & $\mathrm{Fe} 1$ & 0.00000 & 0.00000 & 0.00000 & 26.67011 & 0.19834 \\
\hline Atom \# 5 & $\mathrm{C} 1$ & 1.57434 & 0.00000 & 0.00000 & 11.31410 & -1.70008 \\
\hline Atom \# 6 & $\mathrm{N} 1$ & 1.29315 & 0.00000 & 0.00000 & 5.45694 & 5.05972 \\
\hline Atom \# 7 & $\mathrm{O} 1$ & 8.81707 & 0.00000 & 0.00000 & -5.29073 & 0.99451 \\
\hline Atom \# 8 & $\mathrm{O} 2$ & 0.25000 & 0.25000 & 0.25000 & 9.52497 & 0.36941 \\
\hline Atom \# 9 & $\mathrm{O} 3$ & 0.33265 & 0.33265 & 0.33265 & 17.61880 & 0.38737 \\
\hline
\end{tabular}

FWHM Parameters

\begin{tabular}{|l|l|l|l|}
\hline & U & V & W \\
\hline Coefficients & 3.373407 & -1.695880 & -0.015647 \\
\hline
\end{tabular}

Table S6. Lattice parameter value for as-prepared, discharged and charged electrodes.

\begin{tabular}{|c|c|c|}
\hline Sample & Cell-Parameters & $\chi^{2}$ value $\left(\mathbf{C h i}^{2}\right)$ \\
\hline KCuHCF powder & $\begin{array}{c}\mathrm{a}=\mathrm{b}=\mathrm{c}=10.157, \\
\alpha=\beta=\gamma=90^{\circ}\end{array}$ & 0.915 \\
\hline $\begin{array}{c}\text { Discharged electrode } \\
\left(\mathrm{Ca} \mathrm{a}_{\mathrm{x}} \mathrm{CuHCF}\right)\end{array}$ & $\begin{array}{c}\mathrm{a}=\mathrm{b}=\mathrm{c}=10.125, \\
\alpha=\beta=\gamma=90^{\circ}\end{array}$ & 0.855 \\
\hline Charged electrode (CuHCF) & $\begin{array}{c}\mathrm{a}=\mathrm{b}=\mathrm{c}=10.170, \\
\alpha=\beta=\gamma=90^{\circ}\end{array}$ & 1.20 \\
\hline
\end{tabular}



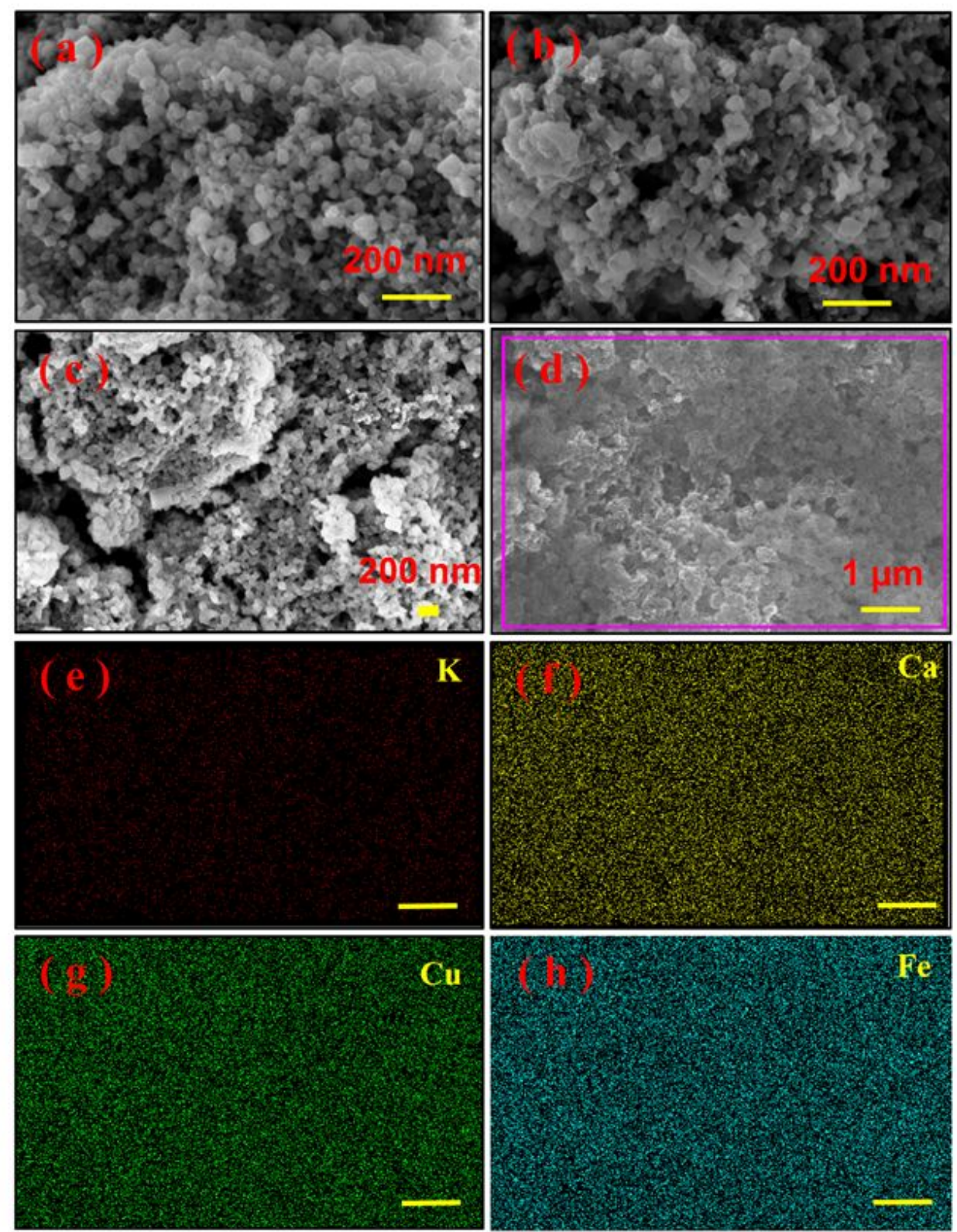

Figure S11. (a) Top-view FEG-SEM image of (a) As-prepared (scale bar $=1 \mu \mathrm{m}$ ), (b) Ca-inserted $($ scale bar $=2 \mu \mathrm{m}),(\mathrm{c})$ Ca-extracted $($ scale bar $=200 \mathrm{~nm})$ CuHCF electrode, $(\mathrm{d}-\mathrm{h})$ elemental mapping of the selected area of discharge electrode (scale bar $=1 \mu \mathrm{m}$ ), (d) selected area (e) potassium, (f) calcium, (g) copper, and (h) Iron. 


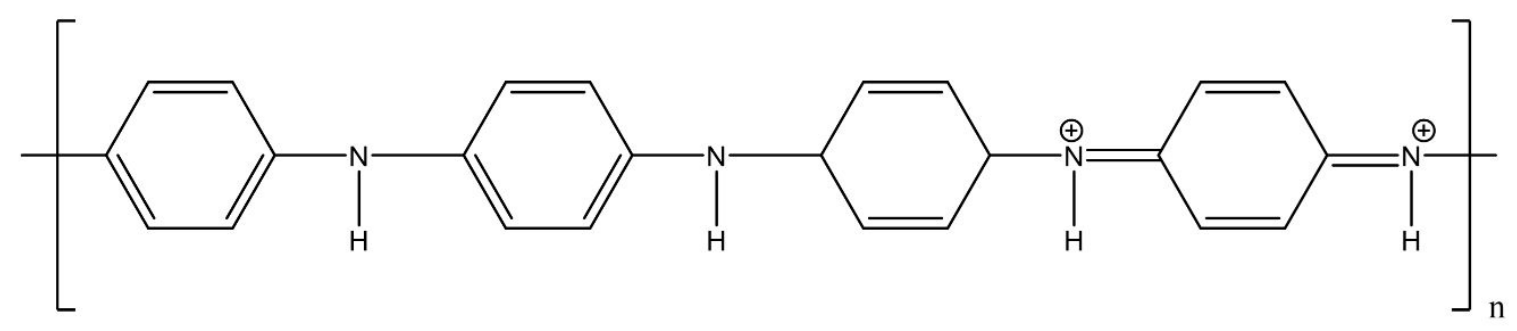

Emeraldine Salt

Figure S12. Molecular structure of Emeraldine salt.

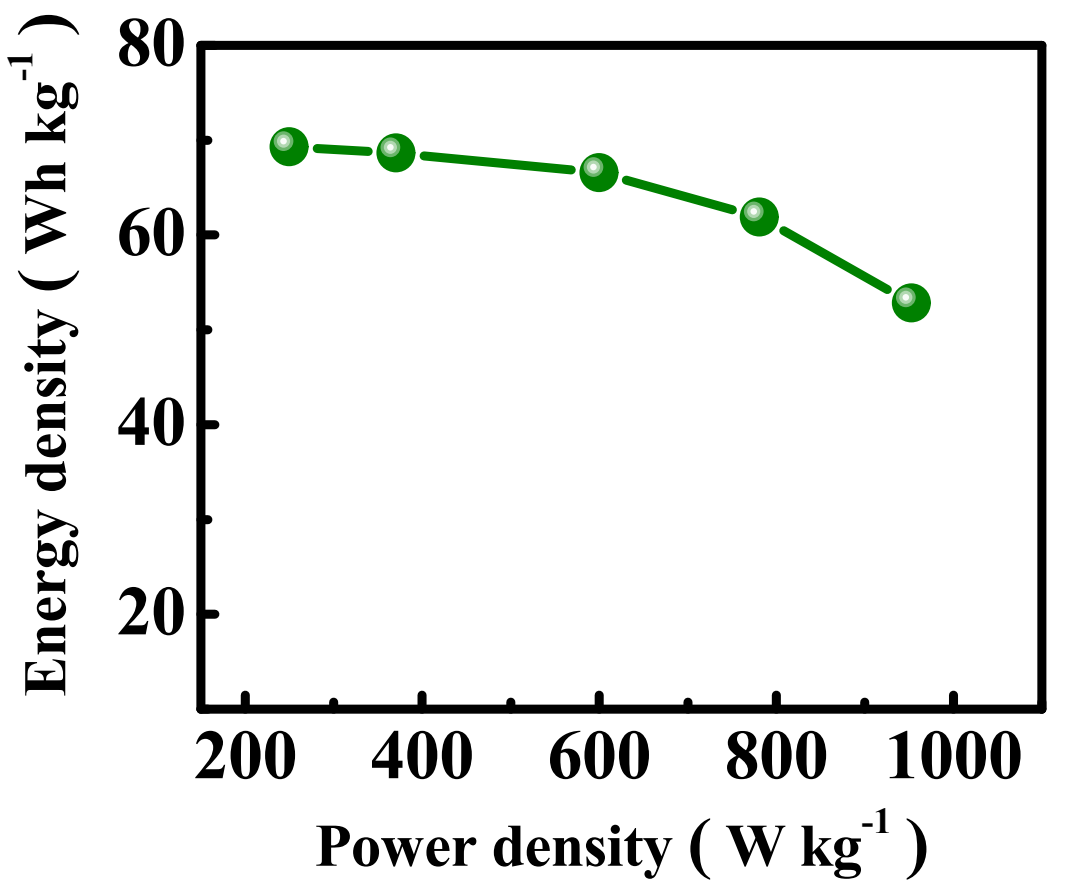

Figure S13. Ragone plot of $\mathrm{Ca}_{\mathrm{x}} \mathrm{CuHCF} / \mathrm{PANI}$ aqueous $\mathrm{Ca}$-ion battery. 


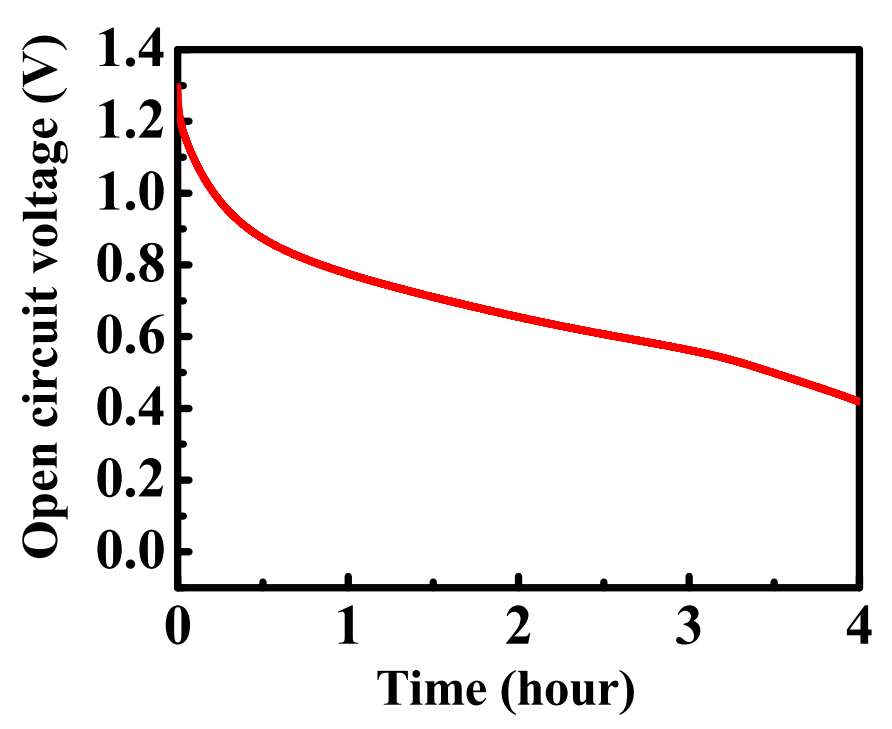

Figure S14. The open-circuit potential decay of fully charged aqueous Ca-ion battery in $2.5 \mathrm{M}$ $\mathrm{Ca}\left(\mathrm{NO}_{3}\right)_{2}$ electrolyte.

\section{Experimental details of XANES and EXAFS study}

XANES and EXAFS measurements on ex situ mode of the copper hexacyanoferrate electrode samples were performed at the Energy Scanning EXAFS beamline (BL-9) at Indus-2 Synchrotron source (2.5 GeV), Raja Ramanna Centre for Advanced Technology (RRCAT), Indore, India. ${ }^{2-5}$ The beamline operates in the photon energy range of 4 to $25 \mathrm{KeV} .^{2}$ The beamline optics consists of an $\mathrm{Rh} / \mathrm{Pt}$-coated collimating meridional cylindrical mirror, which is used for collimation of the beam. This mirror is also used prior to the double crystal monochromator (DCM) to enable higher harmonic rejection to a certain extent. The collimated beam is monochromatized by a $\mathrm{Si}(111)(2 \mathrm{~d}$ $=6.2709)$ based double crystal monochromator (DCM). The second crystal of the DCM is a sagittal cylindrical crystal, which is used for horizontal focusing of the beam, while another Rh/Pt- 
coated bendable post mirror that faces downward is used to vertically focus the beam at the sample position. $^{2}$

In the case of the present samples, the data have been recorded at the $\mathrm{Cu} / \mathrm{Fe} \mathrm{K}$-edge in the transmission mode. To measure the transmission mode, three ionization chambers $(300 \mathrm{~mm}$ in length each) have been used for data collection, one ionization chamber to measure the incident flux $\left(I_{0}\right)$, the second one to measure the transmitted flux $\left(I_{t}\right)$, and the third ionization chamber to measure the EXAFS spectrum of a reference metal foil for energy calibration. Appropriate gas pressure and gas mixtures have been chosen to achieve absorption of $10-20 \%$ in the first ionization chamber and $70-90 \%$ in the second ionization chamber to improve the signal to noise ratio. The absorption coefficient, $\mu$, is obtained using the relation;

$$
I_{T}=I_{0} e^{-\mu x}
$$

where $x$ is the thickness of the absorber, and the spectrum is obtained as a function of energy by scanning the monochromator over the specified range. Higher harmonics in the $\mathrm{X}$-ray were rejected by detuning the second crystal of the DCM by using the piezo motor such that the flux of the beam at the outlet of the DCM is reduced to less than $30 \%$ of the flux at its inlet.

For the EXAFS analysis $(\mu(E) v s . E)$ of the three samples, the oscillations in the absorption spectra $\mu(E)$ have been converted to the absorption function, $\chi(E)$, which is defined as follows:

$$
\chi(E)=\frac{\mu(E)-\mu_{0}(E)}{\Delta \mu_{0}\left(E_{0}\right)}
$$


where $E_{0}$ is the absorption edge energy, $\mu_{0}\left(E_{0}\right)$ is the bare atom background, and $\Delta \mu_{0}\left(E_{0}\right)$ is the step in the $\mu(E)$ value at the absorption edge. The energy-dependent absorption coefficient, $\chi(E)$ , has been converted to the wavenumber dependent absorption coefficient, using the relation,

$$
K=\sqrt{\frac{2 m\left(E-E_{0}\right)}{\mathrm{h}^{2}}}
$$

where $\mathrm{m}$ is the electron mass. $\chi(k)$ is weighted by $k^{2}$ to amplify the oscillation at a high $k$, and the $\chi(k) k^{2}$ functions are Fourier transformed in the $R$ space to generate the $\chi(R)$ versus $R$ plots in terms of the real distances from the center of the absorbing atom. A set of EXAFS data analysis programs available within the Demeter software package has been used to analyze EXAFS data. ${ }^{7}$ This includes background reduction and Fourier transforms to derive the $\chi(R)$ versus $R$ spectra from the absorption spectra (using ATHENA software); to generate the theoretical EXAFS spectra, which starts from an assumed crystallographic structure (using ATOMS subroutine); and finally, to fit the experimental data with the theoretical spectra using ARTEMIS software. ${ }^{2}$ During the fitting, bond distances, coordination numbers (including scattering amplitudes) and disorder (Debye-Waller) factors $\left(\sigma^{2}\right)$, which give the mean square fluctuations in the distances, have been used as fitting parameters. The goodness of fit has been determined by the value of the $R_{\text {factor }}$, which is defined by:

$$
R_{\text {factor }}=\sum \frac{\left[\operatorname{Im}\left(\chi_{\text {dat }}\left(r_{i}\right)-\chi_{\text {th }}\left(r_{i}\right)\right]^{2}+\left[\operatorname{Re}\left(\chi_{\text {dat }}\left(r_{i}\right)-\chi_{\text {th }}\left(r_{i}\right)\right]^{2}\right.\right.}{\left[\operatorname{Im}\left(\chi_{\text {dat }}\left(r_{i}\right)\right]^{2}+\left[\operatorname{Re}\left(\chi_{\text {dat }}\left(r_{i}\right)\right]^{2}\right.\right.}
$$

where, $\chi_{\text {dat }}$ and $\chi_{\text {th }}$ refer to the experimental and theoretical $\chi(r)$ values, respectively, and Im and Re refer to the imaginary and real parts of the respective quantities.

The $\chi(R) R$ plots that are generated at the $\mathrm{Cu}$ and $\mathrm{Fe} \mathrm{K}$-edges by using Fourier transform a range of $k=2.0-10 \AA^{-1}$ from the $\mu(E)$ versus $E$ spectra following the methodology described above are 
shown in Figure 6 at the $\mathrm{Cu}$ and $\mathrm{Fe} \mathrm{K}$-edges for the $\mathrm{CuHCF}$ sample. Theoretical $\chi(R)$ versus $R$ plots at the $\mathrm{Cu}$ and $\mathrm{Fe} \mathrm{K}$-edges of the as-prepared, fully reduced, and fully oxidized samples were generated by assuming a pure $\mathrm{CuHCF}$ structure of the samples. In the fit procedure, apart from the typical XAS parameters such as the bond distance $(R)$, the Debye Waller factor $\left(\sigma^{2}\right)$, and the global amplitude variable (amp), we have also varied the phase fraction $\mathrm{x}$. 
Table S7. A comparative summary of different reported aqueous multivalent-ion batteries

\begin{tabular}{|c|c|c|c|c|c|c|}
\hline Cathode|Anode & Electrolyte & $\begin{array}{l}\text { Charge } \\
\text { carrier }\end{array}$ & $\begin{array}{c}\text { Average } \\
\text { voltage }\end{array}$ & $\begin{array}{c}\text { Specific } \\
\text { energy } \\
\left(\mathbf{W h ~ K g}^{-1}\right)\end{array}$ & $\begin{array}{c}\text { capacity } \\
\text { retention } \\
\text { @cycle } \\
\text { number }\end{array}$ & Reference \\
\hline $\mathrm{ZnHCF} \mid \mathrm{Zn}$ & $1 \mathrm{M} \mathrm{ZnSO}_{4}$ & $\mathrm{Zn}^{2+}$ & 1.7 & 60 & 76\%@100 & 8 \\
\hline NiHCF|Ployimide & $1 \mathrm{M} \mathrm{MgSO}_{4}$ & $\mathrm{Mg}^{2+}$ & 0.6 & 33 & 60\%@5000 & 9 \\
\hline $\mathrm{Ca}_{0.3} \mathrm{CuHCF} \mid \mathrm{PNDIE}$ & $\begin{array}{c}2.5 \mathrm{M} \\
\mathrm{Ca}\left(\mathrm{NO}_{3}\right)_{2} \\
\end{array}$ & $\mathrm{Ca}^{2+}$ & 1.2 & 54 & 90\%@1000 & 10 \\
\hline$\alpha-\mathrm{MnO}_{2} \mid \mathrm{Zn}$ & $1 \mathrm{M} \mathrm{ZnSO}_{4}$ & $\mathrm{Zn}^{2+}$ & 1.3 & 175 & 67\%@100 & 11 \\
\hline $\mathrm{Zn}_{0.25} \mathrm{~V}_{2} \mathrm{O}_{5} \mid \mathrm{Zn}$ & $1 \mathrm{M} \mathrm{ZnSO}_{4}$ & $\mathrm{Zn}^{2+}$ & 0.8 & 150 & 80\%@1000 & 12 \\
\hline $\mathrm{Al}_{0.2} \mathrm{CuHCF} \mid \mathrm{AC}$ & $\begin{array}{c}1 \mathrm{M} \\
\mathrm{Al}\left(\mathrm{NO}_{3}\right)_{2}\end{array}$ & $\mathrm{Al}^{3+}$ & 0.4 & 13 & 90\%@1000 & 13 \\
\hline $\mathrm{CuHCF} \mid \mathrm{Zn}$ & $\begin{array}{l}20 \mathrm{mM} \\
\mathrm{ZnSO}_{4}\end{array}$ & $\mathrm{Zn}^{2+}$ & 1.7 & 34 & 96\%@100 & 14 \\
\hline$\beta-\mathrm{MnO}_{2} \mid \mathrm{Zn}$ & $\begin{array}{c}3 \mathrm{M} \\
\mathrm{Zn}\left(\mathrm{CF}_{3} \mathrm{SO}_{3}\right)_{2} \\
+ \\
0.1 \mathrm{M} \\
\mathrm{Mn}\left(\mathrm{CF}_{3} \mathrm{SO}_{3}\right)_{2}\end{array}$ & $\mathrm{Zn}^{2+}$ & 1.3 & 159 & 94\%@2000 & 15 \\
\hline $\mathrm{Ca}_{\mathrm{x}} \mathrm{CuHCF} \mid \mathrm{PANI}$ & $\begin{array}{c}2.5 \mathrm{M} \\
\mathrm{Ca}\left(\mathrm{NO}_{3}\right)_{2} \\
\end{array}$ & $\mathrm{Ca}^{2+}$ & 0.6 & 53 & 95\%@200 & This work \\
\hline
\end{tabular}




\section{REFERENCES}

(1) Momma, K.; Izumi, F. VESTA 3 for Three-Dimensional Visualization of Crystal, Volumetric and Morphology Data. J. Appl. Crystallogr. 2011, 44, 1272-1276.

(2) Sen, U. K.; Johari, P.; Basu, S.; Nayak, C.; Mitra, S. An Experimental and Computational Study to Understand the Lithium Storage Mechanism in Molybdenum Disulfide. Nanoscale 2014, 6, 10243-10254.

(3) Panda, M. R.; Raj K, A.; Ghosh, A.; Kumar, A.; Muthuraj, D.; Sau, S.; Yu, W.; Zhang, Y.; Sinha, A. K.; Weyland, M.; et al. Blocks of Molybdenum Ditelluride: A High Rate Anode for Sodium-Ion Battery and Full Cell Prototype Study. Nano Energy 2019, 64, 103951.

(4) Singh, S.; Anish Raj, K.; Panda, M. R.; Sen, R.; Johari, P.; Sinha, A. K.; Meena, S. S.; Mitra, S. Study of Higher Discharge Capacity, Phase Transition, and Relative Structural Stability in Li2FeSiO4 Cathode upon Lithium Extraction Using an Experimental and Theoretical Approach and Full Cell Prototype Study. ACS Appl. Energy Mater. 2019, 2, 6584-6598.

(5) Sarkar, A.; Sinha, A. K.; Mitra, S. Nanostructured Vanadium Tri-Oxides, as a Long Life and High Performance Anode for Sodium-Ion Battery. Electrochim. Acta 2019, 299, 914 925.

(6) Koningsberger, D. C.; Prins, R. X-Ray Absorption: Principles, Applications, Techniques of EXAFS, SEXAFS and XANES; Koningsberger, D. C., Prins, R., Eds.; Wiley: New York, 1988.

(7) Newville, M.; Ravel, B.; Haskel, D.; Rehr, J. J.; Stern, E. A.; Yacoby, Y. Analysis of Multiple-Scattering XAFS Data Using Theoretical Standards. Phys. B 1995, 208-209, $154-156$.

(8) Zhang, L.; Chen, L.; Zhou, X.; Liu, Z. Towards High-Voltage Aqueous Metal-Ion Batteries beyond 1.5 V: The Zinc/Zinc Hexacyanoferrate System. Adv. Energy Mater. 2015, 5, 1400930.

(9) Chen, L.; Bao, J. L.; Dong, X.; Truhlar, D. G.; Wang, C. Aqueous Mg-Ion Battery Based 
on Polyimide Anode and Prussian Blue Cathode. ACS Energy Lett. 2017, 2, 1115-1121.

(10) Gheytani, S.; Liang, Y.; Wu, F.; Jing, Y.; Dong, H.; Rao, K. K.; Chi, X.; Fang, F.; Yao, Y. An Aqueous Ca-Ion Battery. Adv. Sci. 2017, 4, 1700465 (1-7).

(11) Xu, C.; Li, B.; Du, H.; Kang, F. Energetic Zinc Ion Chemistry: The Rechargeable Zinc Ion Battery. Angew. Chemie - Int. Ed. 2012, 51, 933-935.

(12) Kundu, D.; Adams, B. D.; Duffort, V.; Vajargah, S. H.; Nazar, L. F. A High-Capacity and Long-Life Aqueous Rechargeable Zinc Battery Using a Metal Oxide Intercalation Cathode. Nat. Energy 2016, 1, 16119.

(13) Li, Z.; Xiang, K.; Xing, W.; Carter, W. C.; Chiang, Y. M. Reversible Aluminum-Ion Intercalation in Prussian Blue Analogs and Demonstration of a High-Power AluminumIon Asymmetric Capacitor. Adv. Energy Mater. 2015, 5, 1401410.

(14) Trócoli, R.; La Mantia, F. An Aqueous Zinc-Ion Battery Based on Copper Hexacyanoferrate. ChemSusChem 2015, 8, 481-485.

(15) Zhang, N.; Cheng, F.; Liu, J.; Wang, L.; Long, X.; Liu, X.; Li, F.; Chen, J. Rechargeable Aqueous Zinc-Manganese Dioxide Batteries with High Energy and Power Densities. Nat. Commun. 2017, 8, 405. 